\title{
General principles of recovery of overdue vaccination of children
}

\author{
Principii generale de recuperare a vaccinării restante a copiilor
}

\begin{abstract}
Immunization is one of the most effective preventive health measures. The number of cases of most vac-cine-preventable illnesses declined by more than 90 percent after routine childhood immunizations were in-troduced. Vaccination programs directly benefit the immunized child. They also indirectly benefit unimmu-nized persons through community immunity. Community immunity occurs when the portion of the population that is immune to the infection is large enough to decrease the risk of transmission. Community immunity protects children who are too young for immunization and persons with contraindications to vaccines.Chil-dren who are behind on vaccines should be caught up using the minimum age for first dose and the minimum intervals between doses.
\end{abstract}

Keywords: children, vaccine, immunization schedules, catch-up schedules

\section{REZUMAT}

Imunizarea este una dintre cele mai eficiente măsuri de prevenire a îmbolnăvirilor. Numărul cazurilor de îmbolnăviri care pot fi prevenite prin vaccinare a scăzut cu mai mult de $90 \%$ după introducerea de rutină a imunizările din copilărie. Programele de vaccinare au beneficii directe pentru copilul imunizat, dar şi indirecte, prin imunitatea comunitară. Imunitatea comunitară apare atunci când procentul de populaţie imunizată împotriva infecţiei este suficient de mare pentru a reduce riscul de transmitere a bolii infecţioase. Imunitatea comunitară protejează copiii care sunt prea mici pentru imunizare, dar şi persoanele care au contraindicaţii la vaccinuri. Copiii care nu au fost vaccinaţi conform programului de imunizare ar trebui să fie recuperaţi utilizând reguli pentru vaccinarea restantă, precum vârsta minimă pentru prima doză şi intervalele minime între doze.

Cuvinte cheie: copil, vaccin, schemă de imunizare, schemă de recuperare

Activitatea preventivă reprezintă o componentă importantă în practica medicului de familie, alături de activitatea curativă, de monitorizarea activă a afecțiunilor cronice, de activitatea de recuperare şi de cea paliativă.

În cadrul activității preventive, alături de consiliere, screening, chimioprofilaxie, examinări periodice de bilanț, imunoprofilaxia prin vaccinare reprezintă principala activitate preventivă ce se adresează cu precădere sugarului şi copilului mic, dar şi altor categorii de vârstă (bolnavi cronici, că- lătorilor). Un număr foarte mare de boli pot fi prevenite prin vaccinarea de rutină a copilului. Introducerea în ultimele decenii, pe scară largă, a imunizărilor împotriva difteriei, tusei convulsive, tetanosului, poliomielitei, rujeolei, rubeolei, oreionului, ca şi a altor vaccinări, a dus la scăderea dramatică a cazurilor de îmbolnăvire (1).

În prezent, în Programul Naţional de Imunizare există vaccinuri pentru principalele boli ale copilăriei, dar şi pentru alte boli care ne plasează în categoria țărilor cu risc endemic (ex.: antihepatita B). 
TABELUL 1. Programul Național de Imunizare-România 2018

\begin{tabular}{|l|l|c|}
\hline Vârsta recomandată & Tipul de vaccinare & Comentarii \\
\hline $\begin{array}{l}\text { Primele 24 de ore } \\
\text {-7 zile }\end{array}$ & $\begin{array}{l}\text { Hep B } \\
\text { BCG }\end{array}$ & În maternitate \\
\hline luni & DTPa-VPI-Hib-Hep B, Pneumoconjugat & Medic de familie \\
\hline 4 luni & DTPa-VPI-Hib-Hep B, Pneumoconjugat & Medic de familie \\
\hline 11 luni & DTPa-VPI-Hib-Hep B, Pneumoconjugat & Medic de familie \\
\hline 12 luni & ROR & Medic de familie \\
\hline 5 ani & ROR & Medic de familie \\
\hline 6 ani & DTPa-VPI & Medic de familie \\
\hline 14 ani & $\begin{array}{l}\text { Vaccin di ero-tetanic adulţi/vaccin } \\
\text { di ero-tetano-pertussis acelular }\end{array}$ & Medic de familie \\
\hline
\end{tabular}

Schema de imunizări în România, în anul 2018 (Tabelul 1), cuprinde printre vaccinări obligatorii: vaccinarea antihepatită $\mathrm{B}$, vaccinarea împotriva bacilului Calmette-Guérin (BCG), vaccinarea împotriva difteriei (D), vaccinarea împotriva tetanosului (T), vaccinarea împotriva tusei convulsive $(\mathrm{Pa})$, vaccinarea împotriva poliomielitei (VPI), vaccinare antiHaemophilus influenzae tip B (Hib), vaccinare anti-pneumococică (PCV13), vaccinare anti-anti-rujeolică-rubeolică-urliană (ROR).

\section{Acoperirea vaccinală}

În ultima perioadă, numărul copiilor care nu sunt imunizați conform Programului Naţional de Imunizare a crescut foarte mult. România are una din cele mai scăzute valori de acoperire vaccinală din Europa, acoperire vaccinală care s-a înrăutăţit treptat (2). Factorii care au contribuit la acest fenomen sunt reprezentați de:

- factori demografici: migrația părinților, însoțiti de copii, care nu sunt luați în evidență în vederea imunizării în noua localitate de domiciliu sau copii rămaşi în grija rudelor

- factori comportamentali: părinți care se lasă influențaţi de diferite opinii antivaccinare şi care, de cele mai multe ori, chiar întrerup schema de vaccinare a copiilor

- factori economici - lipsa episodică a aprovizonării cu vaccinuri

- factori legislativi - lipsa unei legislații privind obligativitatea vaccinării, obligativitatea informării, consimțământ informat sau prezumat al părintelui.

Valorile optime de acoperire vaccinală depind de vârsta copilului recomandată pentru vaccinare, dar şi de tipul de vaccin. Se consideră ca valoare optimă de acoperire vaccinală imunizarea a peste
90\% pentru vaccinurile recomandate în Programul Naţional de Imunizare, până la vârsta de 6 ani. Pentru adolescenți, se consideră o valoare optimă de acoperire vaccinală de peste $88 \%$ pentru dT şi peste $65 \%$ pentru vaccinarea HPV (3). O revizuire sistematică a 55 studii randomizate şi observaționale a concluzionat că mesajele de reamintire şi rechemare sunt eficiente în creşterea ratelor de imunizare în asistența medicală primară (cu o medie de 8\%) (4).

\section{Principii de recuperare a vaccinărilor restante}

Planul de recuperare a vaccinărilor restante trebuie să țină cont de schema anterioară de vaccinare, de vârsta copilului, precum şi de o serie de principii generale de recuperare vaccinală (Tabelul 2) (5).

Toate schemele de recuperare a vaccinării trebuie să respecte următoarele principii:

- vârsta minimă de administrare a primei doze

- numărul de doze recomandate

- intervalul minim dintre doze

- schema de administrare a vaccinurilor combinate

- vârsta maximă de administrare a ultimei doze (5).

Pentru calculul intervalelor dintre doze, se consideră că intervalul de 4 săptămâni este egal cu 28 zile, iar Intervalele mai mari sau egale cu 4 luni se determină pe luni calendaristice. Dozele de vaccin administrate $\leq 4$ zile înainte de vârsta sau intervalul minim sunt considerate valide. Dozele din orice vaccin administrate peste $\geq 5$ zile decât intervalul minim sau vârsta minimă nu trebuie să fie considerate valabile şi trebuie repetate în funcție de vârstă. Doza repetată trebuie să fie distanţată după doza nevalidă cu intervalul minim recomandat (6).

TABELUL 2. Repattiția pe vârstă a deceselor cauzate de rujeolă (2016-2018)

\begin{tabular}{|l|c|c|c|c|c|c|c|c|}
\hline Vârstă & $<6$ luni & $6-9$ luni & $9-12$ luni & $1-4$ ani & $5-10$ ani & $11-18$ ani & $>18$ ani & total \\
\hline Nr. decese & 14 & 11 & 6 & 15 & 2 & 3 & 4 & 55 \\
\hline
\end{tabular}




\section{Principii de recuperare a vaccinării antihepatită $B$}

Vaccinul antihepatitic B - Vaccinarea se face la naştere, la 2, 4, 11 luni pentru toți copiii, infecția cu virus hepatic $\mathrm{B}$ fiind practic endemică în România. În România, studiile au demonstrat că vaccinarea tuturor nou-născuților, copiilor şi/sau adolescenților în regim de 3-4 doze de vaccin antihepatită B are o eficacitate de peste $84 \%$ în prevenirea infecției cu VHB şi peste $80 \%$ în prevenirea apariţiei hepatitei cronice $\mathrm{B}$. Recuperarea vaccinării antihepatită B se face respectând următoarele reguli:

- vârsta minimă de administrare a primei doze este la naştere

- numărul de doze recomandate este de 3 doze, dacă se utilizează univaccin, sau 4 doze, dacă se utilizează multivaccinul (DTPa-VPI-HepBHib)

- intervalul minim dintre doze: între prima şi a doua doză de vaccin antihepatită B trebuie să fie minimum 4 săptămâni, între a două şi a treia doză intervalul minim este de 8 săptămâni, între prima şi a treia doză trebuie să fie minimum16 săptămâni, între a treia şi a patra doză de vaccin antihepatită B trebuie să fie minimum 8 săptămâni (6).

\section{Principii de recuperare a vaccinării anti-DTP-VPI- Hib (vaccin împotriva difteriei, tetanosului, tusei convulsive, poliomielitei, infecţiei cu Haemophilus influenzae tip B)}

Vaccinarea DTP a fost introdusă în România în 1961. Ținta programului național de imunizare este menținerea unui nivel înalt de imunitate protectivă prin vaccinare, pentru eliminarea difteriei, a tetanosului neonatal şi menținerea incidenței tusei convulsive de 1 caz la 100.000 de locuitori. Folosirea de poliovirusuri inactivate (VPI) are imunogenitate similară şi efecte secundare minime. Vaccinarea împotriva infecțiilor cu Haemophilus influenzae tip B este introdusă în schema obligatorie de imunizare în România din anul 2009. Primovaccinarea se face la vârsta de 2, 4, 11 luni, urmată de rapelul 1 la vârsta de 6 ani.

Recuperarea vaccinării DTPa-IPV-Hib-HepB se face respectând următoarele reguli:

- vârsta minimă de administrare a primei doze de vaccin este de 6 săptămâni

- numărul de doze recomandate de vaccin este de 3 doze

- intervalul minim dintre doze: între prima şi a doua doză de vaccin trebuie să fie minimum 8 săptămâni, între a două şi a treia doză de vaccin trebuie să fie minimum 16 săptămâni; ultima doză de vaccin anti-DTPa-IPV-HibHepB nu se recomandă mai tărziu de 3 ani (6).

Principii de recuperare a vaccinării anti-DTP-VPI (vaccin împotriva difteriei, tetanosului, tusei convulsive, poliomielitei)

Recuperarea vaccinării DTPa-IPV se face respectând următoarele reguli:

- vârsta minimă de administrare a primei doze trebuie să fie de 4 ani

- numărul de doze recomandate - o doză

\section{Principii de recuperare a vaccinării anti-Hib (vaccin împotriva infecţiei cu Haemophilus influenzae tip B)}

Recuperarea vaccinării infecțiilor cu Haemophilus influenzae tip B se face respectând următoarele reguli:

- Dacă prima doză de vaccin anti-Hib se administrează la 7-11 luni - se recomandă administrarea celei de-a doua doze de vaccin antiHib cu cel puțin 4 săptămâni mai târziu şi o doză 3 (finală) la 12-15 luni sau la 8 săptămâni după cea de-a doua doză de vaccin antiHib.

- Dacă prima doză de vaccin anti-Hib se administrează la 12-14 luni - se recomandă administrarea celei de-a doua doze la cel puțin 8 săptămâni după prima doză, fiind şi ultima doză de vaccin anti-Hib.

- Dacă prima doză de vaccin anti-Hib se administrează înainte de 12 luni şi a doua doză înainte de 15 luni - se recomandă administrarea celei de-a treia doze de vaccin anti-Hib (cea finală) la 8 săptămâni după cea de-a doua doză de vaccin.

- Dacă copilul este nevaccinat la 15-59 luni, se recomandă administrarea unei singure doze de vaccin anti-Hib.

\section{Principii de recuperare a vaccinării antipneumococcice}

Streptococus pneumoniae (pneumococul) este unul dintre principalii agenți patogeni infecțioşi la vârsta copilăriei, precum şi la persoanele vârstnice şi/sau care au boli cronice.

Pneumococul colonizează tractul respirator superior şi poate provoca următoarele tipuri de îmbolnăvire: infecții respiratorii superioare, incluzând otita medie şi sinuzita; pneumonie şi alte infecții ale tractului respirator inferior; infecție diseminată invazivă, care include bacteriemia, septicemia şi meningita. 
Scopul vaccinării antipneumococice este de a preveni boala pneumococică invazivă cu ajutorul vaccinurilor pneumococice.

Recuperarea vaccinării antipneumococcice se face respectând următoarele reguli:

- numărul de doze recomandate diferă în funcție de vârsta copilului, astfel, se recomandă 3 doze de vaccin dacă vârsta copilului este sub 2 ani şi o doză de vaccin antipneumococcic dacă vârsta copilului este peste 2 ani.

- intervalul minim dintre doze: între prima şi a doua doză de vaccin antipneumococcic trebuie să fie minimum 8 săptămâni, între a doua şi a treia doză de vaccin antipneumococcic trebuie să fie minimum 16 săptămâni (6).

\section{Principii de recuperare a vaccinării anti-rujeolă- oreion-rubeolă}

Iniţial, a fost introdus vaccinul antirujeolic în 1979 la copilul mic, iar vaccinarea antirubeolică a fost introdusă la adolescente în anul 2003. În prezent, vaccinarea se face cu trivaccin (rujeolo-oreion-rubeolă) la 12 luni şi 5 ani. Se folosesc vaccinuri cu virusuri vii atenuate. În condiţii epidemiologice speciale, aşa cum este România din anul 2017, de epidemie de rujeolă, se recomandă vaccinarea suplimentară la 9 luni, urmată de vaccinarea la 1 an şi 5 ani. Primele cazuri de rujeolă au fost înregistrate în ianuarie 2016, reprezentând o epidemie comunitară localizată în vestul României. Tulpina virusului rujeolic în cadrul acestei epidemii a fost identificată ca fiind B3, diferită de tulpina endemică D4 uzuală din România. Majoritatea cazurilor au fost raportate de județele Timiş, Arad, Caraş-Severin, Satu-Mare, Braşov, Călăraşi şi Vaslui. Dintre toate cazurile, 56,13\% (7.787) au fost copii sub vârsta de 5 ani, în timp ce 12,71\% (1.763) au avut 20 de ani sau mai mult. Cea mai mare incidență a fost raportată la copiii cu vârsta cuprinsă între 1 şi 4 ani (39,05\%) şi sub 1 an (19,05\%) (7).

\section{BIBLIOGRAFIE}

1. Dumitru Matei, Esenţialul în Medicina de Familie, Editura Medicală Amaltea, ediţia a 3-a, 2016

2. Alexandre de Figueiredo et al. Forecasted trends in vaccination coverage and correlations with socioeconomic factors: A global time-series analysis over 30 years, Lancet, Vol 4, No10, e726-e735, oct 2016

3. Walker T.Y., Elam-Evans L.D., Singleton J.A. et al. National, Regional, State, and Selected Local Area Vaccination Coverage Among Adolescents Aged 13-17 Years - United States, 2016. MMWR Morb Mortal Wkly Rep. 2017;66(33):874

4. Jacobson Vann J.C., Jacobson R.M., Coyne-Beasley T. et al. Patient reminder and recall interventions to improve immunization
Istoricul imunizării ne arată că, din toate cazurile înregistrate, $96,01 \%$ nu au fost imunizate, $2,89 \%$ au avut efectuată o doză de vaccin, în timp ce $1,01 \%$ au avut două doze de vaccin (7). Au fost raportate 55 de decese din ianuarie 2016 până în iunie 2018 (Tabelul 2).

Recuperarea vaccinării anti-rujeolo-oreion-rubeolă se face respectând următoarele reguli:

- vârsta minimă de administrare a primei doze este de 9 luni, în condiții de existență a epidemiei, şi 12 luni in afara epidemiei.

- numărul de doze recomandate diferă în funcție de condițiile epidemiologice speciale $(2$ doze în condiții de absență a epidemiilor, 3 doze în condiții de existență a epidemiilor).

- intervalul minim dintre doze - în condiții de existență a epidemiei, se recomandă administrarea celei de-a doua doze la copilul peste 12 luni.

\section{CONCLUZII}

Activitatea preventivă reprezintă o componentă importantă în practica medicului de familie. În cadrul activității preventive, imunoprofilaxia prin vaccinare reprezintă principala activitate preventivă ce se adresează cu precădere sugarului şi copilului mic, dar şi altor categorii de vârstă. Din cauza scăderii acoperirii vaccinale, este necesară recuperarea copiilor avand schema de vaccinare incompletă. Recuperarea vaccinală se efectuează după reguli de recuperare în funcție de fiecare vaccin.

Schemele de recuperare vaccinală pot include asocierea a 4, 5 sau chiar 6 vaccinuri într-o singură doză vaccinală. Se impune necesitatea cunoaşterii de către medicul de familie atât a principalelor contraindicații şi precauții privind excipienții fiecărui vaccin, a reacțiilor secundare, cât şi a regulilor de recuperare vaccinală, particularizate fiecărui copil, dar şi respectarea tehnicii de vaccinare corectă.

Conflict of interest: none declared Financial support: none declared

rates. Cochrane Database Syst Rev. 2018; 1:CD003941. Epub 2018 Jan 18

5. Dumitru Matei. Îndreptar practic de Medicină de Familie, Editura Medicală Amaltea, ediţia a 3-a, 2017

6. CDC Vaccine Schedules https://www.cdc.gov/vaccines/schedules/hcp/ schedule-app.html\#download

7. Institutul Naţional de Sănătate Publică România - Centrul Naţional de Supraveghere şi Control al Bolilor Transmisibile. Informare săptămânală rujeolă 08.06.2018 